\title{
Challenging The Mandate Of Heaven: Popular Protest in Modern China
}

\section{Citation}

Perry, Elizabeth J. 2001. “Challenging The Mandate Of Heaven: Popular Protest in Modern China." Critical Asian Studies 33 (2) (June): 163-180. doi:10.1080/14672710122544.

\section{Published Version}

10.1080/14672710122544

\section{Permanent link}

http://nrs.harvard.edu/urn-3:HUL.InstRepos:34732134

\section{Terms of Use}

This article was downloaded from Harvard University's DASH repository, WARNING: No applicable access license found.

\section{Share Your Story}

The Harvard community has made this article openly available.

Please share how this access benefits you. Submit a story. 


\title{
CHALLENGING THE MANDATE OF HEAVEN
}

\section{Popular Protest in Modern China}

\author{
Elizabeth J. Perry
}

Arguing that popular protest has played an unusual role in bestowing political legitimacy in China, this article traces continuities in state responses to protest movements from imperial days to the present. The author compares the government's recent handling of three different types of protest: economically motivated actions by hard-pressed workers and farmers, nationalistically inspired demonstrations by patriotic students, and (at greater length) religiously rooted resistance by zealous believers. The central authorities' tolerance toward localized strikes and tax riots, and their overt encouragement of protests against the bombing of the Chinese embassy in Belgrade, contrasts sharply with the harsh and unrelenting campaign of repression that has been directed against Falun Gong adherents. Explanations for these variant state responses are sought in historically grounded assessments of the political implications of different types of popular protest.

No country boasts a more enduring or more colorful history of rebellion and revolution than China. The Chinese tradition of popular upheaval stretches back well beyond this century; indeed, records allow us to trace it as far back as 209 B.C.E. when the Chen She Rebellion helped to topple the mighty Qin empire and give rise to the famous Han dynasty. Over the ensuing millennia, popular protest has formed a constant and consequential theme in Chinese political history.

China's impressive record of rebellion and revolution is due not simply to the country's extraordinary size and longevity, but also to the fact that central elements in Chinese political culture have directly encouraged such protests. The Confucian (or Mencian, to be precise) concept of a "Mandate of Heaven" (tianming) bestowed instant legitimacy upon successful rebel leaders. This 
pragmatic precept differed markedly from European notions of a "divine right of kings" and the Japanese belief in an unbroken line of rulers descending from the Sun Goddess, myths that militated against challenges to the powers-that-be. In imperial China, one who managed to wrest the throne by force thereby gained Confucian sanction for his rule; as the proverb put it bluntly, "He who succeeds is a king or marquis; he who fails is an outlaw." Of course this did not mean that imperial aspirants were free to ignore cultural or normative bounds. Future emperors were expected to demonstrate their claim to the Mandate by means of various divine omens and needed to come to terms with Confucian elites if they were to harbor any hope of a long-lived reign. Still, the relative openness of the system stood in stark contrast to that of other imperial orders. Political challengers in China — be they peasants or foreign invaders — were permitted to make a bid for kingship through popular rebellion.

Although Confucianism was largely discredited in the twentieth century, the connection between mass protest and political legitimacy remained intact. Sun Yat-sen's "Three Principles of the People" helped inspire the 1911 Revolution that toppled two thousand years of imperial rule, while Mao Zedong' s doctrine of "People's War" fueled the Communist victory in 1949 - just as his subsequent call for "continuing the revolution" provided justification of a Cultural Revolution in the mid-sixties. Indeed, one of the principal differences between Chinese and Soviet Communism lies in the former's emphasis on mass criticism and mass campaigns. Like Mencius's Mandate of Heaven, Mao's Mass Line insisted on the reciprocal linkage between leader and led in staking a claim to higher political morality. Whereas Stalin looked to the secret police to enforce top-down order, Mao repeatedly called upon the Chinese masses to engage in class struggle from below. This certainly did not mean that the People's Republic under Mao eschewed the use of state surveillance - quite the contrary - but it was unusual among Communist countries in also requiring ordinary citizens to participate actively in government-sponsored campaigns.

Many assumed that the death of Chairman Mao would spell an end to the importance of mass movements in the People's Republic of China (PRC). Deng Xiaoping announced soon after his accession to power that the era of mass campaigns was indeed over. Actually, however, popular protests - some with at least implicit higher-level encouragement - have continued to punctuate the history of the PRC in the post-Mao period. The Democracy Wall movement of 1978-79, the anti-Japanese demonstrations of 1985, the anti-American protests of 1999, and even the student uprising of 1989 were all stimulated in part by the expectation of support from elements of the central leadership. Although Mao's successors have been less active in instigating political unrest than was the Great Helmsman himself, protesters remain unusually attentive to signals from the central leadership.

Moreover, alongside these expressly political initiatives have occurred a host of other protests - from tax riots to sectarian resistance — that share a remarkable resemblance to patterns of unrest so familiar to students of imperial and Republican China. Farmers have banded together in assaults on tax bureaus to protest the imposition of exorbitant surcharges. Workers have launched strikes 
and slowdowns to signal their dissatisfaction with factory closures and attendant layoffs. Religious sectarians have insisted on practicing their spiritual regimens in bold defiance of government proscriptions.

In light of China's rich and variegated traditions of resistance, rebellion, and revolution, we should be duly skeptical of claims (such as those proffered by many observers during the Tiananmen uprising of 1989) that new outbursts of protest represent a fundamental break with the past. Although initial reactions to the 1989 "democracy movement" stressed its novelty, subsequent reflections on the activities of the protesters - including retrospectives by the principals themselves - questioned the extent to which their behavior constituted a genuine rupture with earlier modes of protest. As Tiananmen activist Liu Xiaobo later conceded,

Most of the resources and methods we made use of to mobilize the masses were ones that the Communist Party itself had used many times before....As soon as we began our revolution, we became extremely conceited - just as if we had reverted to the time of the Cultural Revolution and felt ourselves to be the most revolutionary. As soon as we joined the 1989 protest movement, we considered ourselves to be the most democratic. After all, had we not fasted for democracy and devoted ourselves to it and made sacrifices for it?... Our voice became the only truth. We felt as though we possessed absolute power. ${ }^{1}$

Liu's impassioned reflections are a stinging indictment of the Tiananmen protest as an undemocratic movement that unwittingly recreated many of the

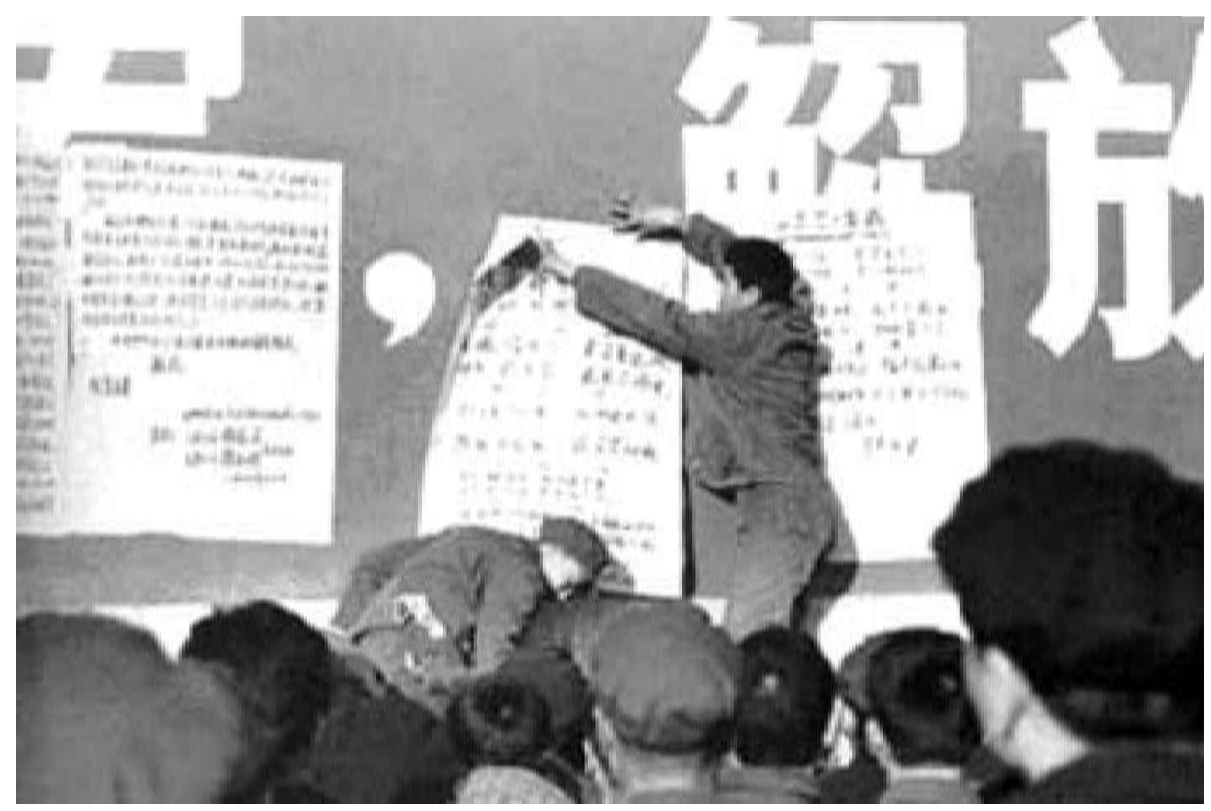

Democracy Wall, Beijing. "The Democracy Wall movement of 1978-79, the anti-Japanese demonstrations of 1985, the anti-American protests of 1999, and even the student uprising of 1989 were all stimulated in part by the expectation of support from elements of the central leadership." (Photo courtesy of Amnesty International/Kristina M. Torgeson. URL: < http:// www.amnesty-usa.org/amnesty/asa/china/torgeson.html>.) 
worst features of Chinese Communist political culture. He suggests that what masqueraded as the sprouts of civil society (e.g., autonomous student and worker associations) or as novel cultural practices (e.g., weddings on the Square) were in reality little more than variations on the repressive theme of Chinese Communist convention. The searing experience of the Cultural Revolution in particular, according to Liu Xiaobo, has inhibited the development of a genuinely democratic perspective among Chinese intellectuals.

While Liu's critique is a poignant reminder that societal initiatives in China continue to reflect the heavy hand of statist influences, we should not thereby conclude that popular protest is forever fated to serve merely as the handmaiden of Communist control. During the 1989 protests, for example, the autonomous workers' federations that sprang up around the country represented a heightened level of antagonism between organized labor and the state in contemporary China.

Challenging the Mandate of Heaven was never easy, but it did periodically occur - in both ancient and modern times. History suggests that a key to the success of such undertakings lay in bridging the (often state-imposed) categories that set various groups of people against one another. Such divisions, although responsible for much of the unrest that has colored the Chinese past, also posed serious obstacles to concerted popular imagination and action against the state. To overcome these hurdles required the intervention of farsighted individuals, who often issued from the lower rungs of the intelligentsia or local elite. Whether drawn from the ranks of students, teachers, militia captains, religious masters, bandit chieftains, or Communist cadres, such leaders have played a catalytic role in converting ongoing strategies of competition into large-scale political movements. The state, too, was a critical variable in the equation; a poorly executed repression effort could stimulate, rather than stymie, the spirit of political protest.

\section{Expectations of Stability}

The advent of a new millennium affords an opportune occasion to take stock of the historical legacy of Chinese protest and its continuing impact on the contemporary scene. The PRC has certainly seen its share of mass movements, many (but by no means all) of which were elite-inspired, if not overtly instigated. According to government pronouncements, however, 1999 was to be different. As the fiftieth anniversary of the founding of the PRC, the final year of the old millennium was supposed to be protest-free - a time for officially orchestrated parades, but not for unofficial demonstrations. Stability, rather than spontaneity, was the watchword of the day.

The year 1999 was seen as potentially problematic not only because it marked a half-century milestone in the history of Communist China, but also because it was a banner anniversary year for other critical events in the record of Chinese protests: the eightieth anniversary of the May Fourth Movement of 1919, the fortieth anniversary of the Tibetan Revolt of 1959, the thirtieth anniversary of the conclusion of the mass mobilization phase of the Cultural Revolution in 1969, the twentieth anniversary of the Democracy Wall movement of 


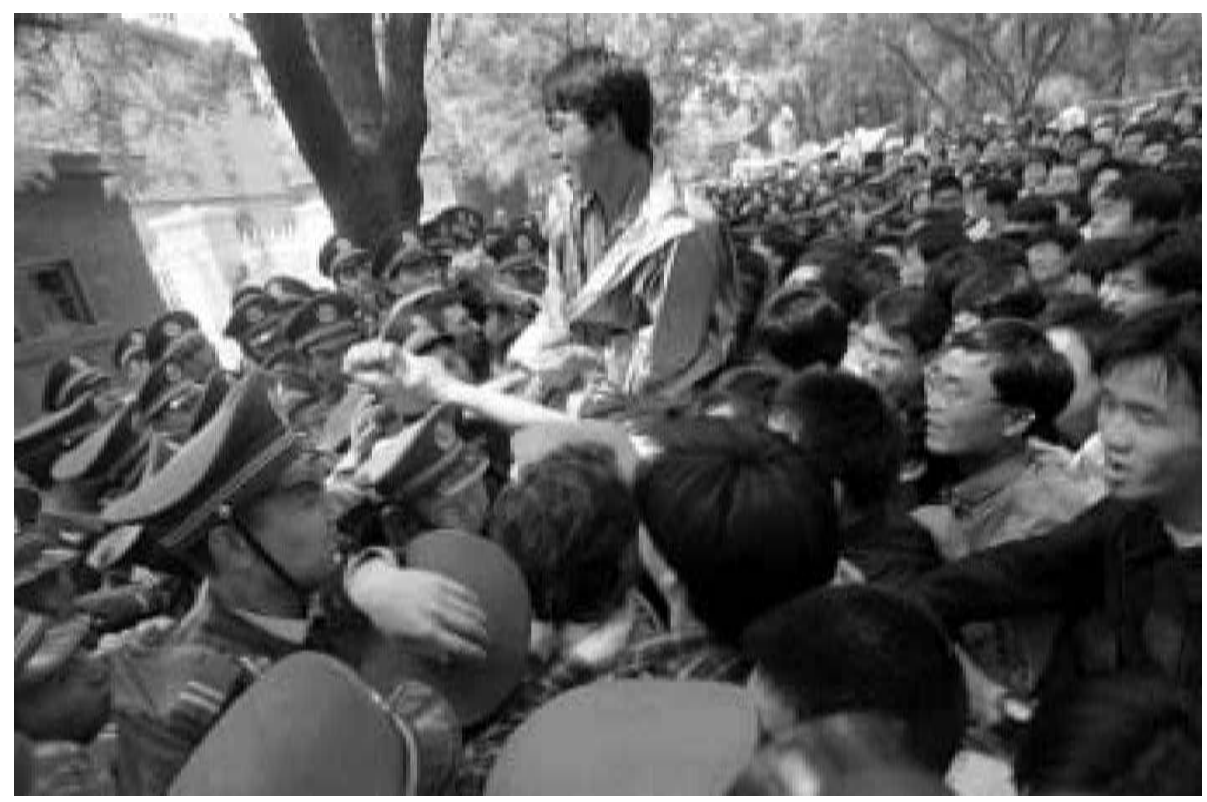

A protestor tries to break police lines in front of the U.S. embassy in Beijing on Sunday, 9 May 1999. "In the case of the 1999 student protests against the [NATO] bombing of China's Belgrade embassy, we find a considerable degree of overt central government support - sanctioning the demonstrations on national television, providing buses to take students to foreign embassies and consulates, and even supplying the slogans that they should shout once they got there." (AP/Wide World Photos/Chien-min Chung)

1979, the tenth anniversary of the Tiananmen uprising and its bloody June 4 suppression in 1989. Inasmuch as the commemoration of anniversaries is itself a common pretext for protest in China, the year was approached with trepidation by the leadership. ${ }^{2}$ To ensure that potential protesters had no space in which to mark these anniversaries, Tiananmen Square was closed for renovations until shortly before the October 1 National Day celebrations. As things developed, however, before the curtain could be rung down on the old millennium, China was rocked with all manner of protests: tax revolts by farmers in the countryside, petition drives by laid-off workers and displaced residents in the cities, student demonstrations against the NATO bombing of the Chinese embassy in Belgrade, and even a convocation of religious sectarians right outside the central leadership compound of Zhongnanhai.

Despite its avowed intention to oppose all forms of protest, the state actually responded in quite different ways to these various expressions of popular discontent. ${ }^{3}$ The government ruthlessly repressed the Falun Gong believers who had amassed peacefully outside Zhongnanhai on April 25, despite the fact that they were arguably the least violent of all the demonstrations that occurred in China that year. Toward the protests by farmers and workers, the authorities showed a considerable degree of tolerance. And officials actively encouraged the student protests that erupted after the Belgrade bombing of May 8 .

These seemingly contradictory government responses make considerably more sense if viewed in historical perspective. The central government's muted response to the protests by farmers and workers has an ancient pedigree. From 
imperial days to the present, economic protests demanding a secure livelihood were generally seen as a signal of local distress that should be dealt with by grassroots officials. As Mencius had emphasized, it was the responsibility of government to provide for the people's welfare. But since economic difficulties tended to be localized, the onus of alleviating them fell to local-level officials county magistrates or provincial governors. Similarly, today it is the mayor of Chongqing municipality or the magistrate of Renshou county who is expected to cope with petitions by laid-off workers or tax revolts by hard-pressed farmers.

"Moral economy" protests launched in the name of subsistence have occurred with remarkable frequency in recent years in both rural and urban China. In 1993, for instance, according to a top-level government report the countryside witnessed some 1.7 million cases of resistance, primarily tax resistance, of which 6,230 cases were classified as "disturbances" (naoshi) that entailed severe damage to persons or property. The confrontations that year exacted a staggering toll of deaths and injuries on some 8,200 township and county officials. ${ }^{4}$ Farmers were not alone in expressing economic grievances. In the final decade of the twentieth century, according to official statistics, more than 1.5 million industrial disputes were officially recorded and processed by arbitration or mediation committees. ${ }^{5}$ Since many more disputes occur than are officially registered, we can assume an impressive level of labor strife as well.

So long as such confrontations limit their demands to calling for a decent livelihood and so long as they remain localized, the central government has generally stayed out of the picture - except to encourage local officials to deal fairly with the protesters. In the case of a taxicab drivers' strike in the city of Changsha, for example, central authorities intervened to persuade the municipal government to rescind its plan to raise license fees to a level beyond the means of many drivers. When tax revolts by farmers have prompted central intervention, it has usually been to remind township and county governments that their fees and surcharges must not exceed 5 percent of farmers' income, as stipulated by national regulations (which have been widely ignored). ${ }^{6}$

In short, the central government - like its predecessors in imperial and Republican China - has demonstrated a certain degree of tolerance and even sympathy toward economically driven protests, provided that they remain clearly bounded in both scale and aspirations. Claims to a basic subsistence that stay within local confines have seldom been deemed especially threatening by Chinese regimes, and so - in contrast to protests motivated by explicitly religious or political agendas — historically have not attracted a great deal of central anxiety or attention.

Nationalistically inspired student unrest is another story altogether, however. In the case of the 1999 student protests against the bombing of China's Belgrade embassy, we find a considerable degree of overt central government support - sanctioning the demonstrations on national television, providing buses to take students to foreign embassies and consulates, and even supplying the slogans that they should shout once they got there. Here, too, the historical lessons are telling. Patriotic student movements have proved politically incendiary in China ever since the Opium Wars of the mid-nineteenth century opened 
Chinese governments to charges of being soft on imperialism. The May Fourth Movement of 1919, which railed against Japanese incursions after World War I, resulted in the dismissal of the three discredited officials who had signed the Treaty of Versailles. More importantly, it helped give rise to the Chinese Communist Party (CCP) itself. The Communist revolution was also at core a movement of nationalistically inspired students, who subsequently reached out to other allies - first workers, then peasants - in an effort to topple a government that they charged was remiss in its responsibility to guard China's national sovereignty.

The current regime is thus deeply afraid of jingoistic student movements, especially if they seem likely to link up with other social groups, and only a few years ago it banned student demonstrations that called for recovering the Diaoyutai (Senkaku) Islands from Japanese control. But with the bombing on 8 May 1999 having created visible martyrs, it was simply too hazardous for the government to try to disallow student demonstrations altogether. Moreover, the incident occurred only four days after the May Fourth anniversary (and less than a month before June Fourth) when historical parallels were on everyone's mind. ${ }^{7}$ Jiang Zemin — like his predecessors in 1919 — risked being accused of failing to protect Chinese sovereignty unless he seemed to be responding at least as vigorously as the students to this affront to national pride. And thus, within hours of the news of the bombing, the regime reversed its policy of discouraging all forms of student activism and allowed, even encouraged, educated youths to take to the streets to express their patriotic outrage. What better way for Jiang Zemin and company to reclaim the glorious mantle of nationalism that had once enveloped their party.

\section{Falun Gong}

Let us turn now, and at greater length, to the Falun Gong campaign - where the authorities adopted a policy of harsh repression, in contrast to the tacit tolerance that they showed toward small-scale economic protests by workers and farmers or the overt support that they provided to nationalistic students. Even more than in these other instances, the Falun Gong case is replete with historical resonance.

As the suppression campaign against Falun Gong suggests, the Chinese state recognizes the dangers inherent in cross-class and cross-territorial expressions of popular protest. While geographically confined movements aimed at improving the economic lot of one social group are (and were) countenanced, movements that spill across jurisdictional and/or occupational boundaries are (and were) viewed as cause for serious central concern. Imperial edicts condemned sectarian groups not only for their heterodox beliefs, but also for their tendency to attract itinerants and merchants as well as settled peasants, to encourage intermingling of the sexes, and to uproot people from their assigned places in the social hierarchy. The breaching of "proper" societal divisions was — along with heterodoxy — grounds for severe repression.

The government-directed campaign against Falun Gong (or "Wheel of Law" as it is often rendered into English) is reminiscent both of Maoist campaigns 


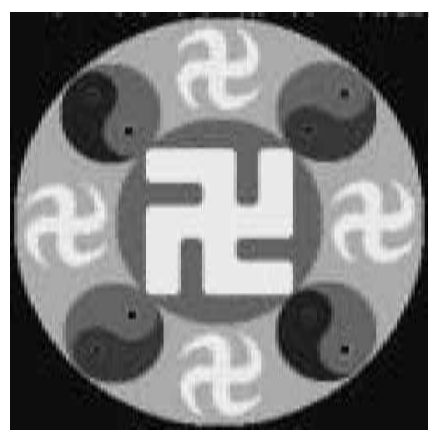

In the Falun emblem the swastika symbol represents the Buddha School and the Taiji (Yin-Yang) symbols represent the Tao School. against alleged "counter-revolutionaries" and of earlier, imperial initiatives against allegedly "heterodox" sectarians. Inasmuch as the current regime tries to distinguish itself sharply from such antecedents, the campaign has exposed a host of ironies that raise the question of just how modern and reformist the post-Mao leadership actually is. In striking out against the Wheel of Law, were Jiang Zemin and company simply reinventing the familiar wheel of repression of heterodox sects forged by their predecessors? And does history offer any clues as to the likely consequences of this heavy-handed state response?

Government propaganda against the practice of Falun Gong dominated both the air waves and the print media for weeks after the campaign got under way in July of 1999. Thousands were reportedly sent to labor camps, and hundreds to prison, in conjunction with the crackdown. Dozens may have died at the hands of the police. This was of course hardly the first time that the post-Mao authorities had struck out against allegedly "sectarian" activities. During the past two decades, the government has cracked down on all manner of secret societies and underground religious groups as well as on rebellions inspired by a variety of folk beliefs. ${ }^{8}$ The fear of qigong practices (or breathing and martial arts exercises) turning into political protests is also not a new concern for the post-Mao leadership. At the time of the 1989 demonstrations, government hotlines were established in the major cities to encourage citizens to report any suspicious behavior by qigong masters. ${ }^{9}$ Nevertheless, the launching of a full-scale campaign against a single organization of this sort is indeed unprecedented. Not since the Suppression of Counter-Revolutionaries Campaign in the early 1950s have we seen such sustained national attention directed to the threat of sectarian resistance, and never before have we witnessed an attack of this kind on but a single target.

Why did the leadership elect to undertake this drastic initiative - an initiative so out of step with its attitude toward labor disputes, tax riots, or even student nationalistic demonstrations? Timing, scale, and composition help to account for the difference. As noted earlier, the year 1999 was approached as a moment of potential trouble by the PRC authorities. Public security officials surely thought they had eliminated the threat of mass demonstrations in the capital when they closed Tiananmen Square for renovations during the first half of the year, conveniently preventing would-be protesters from commemorating May Fourth - or, more dangerous still, June Fourth - at the site of those historic events. Thus they were shocked when 10,000 Falun Gong adherents from all over the country and all walks of life suddenly materialized in front of the leadership compound of Zhongnanhai to demand official recognition of their religious association. While the government had shown increasing flexibility toward localized, interest-based protests in recent years (e.g., demonstrations by laid-off workers at particular factories or in particular cities), it remained deeply 
fearful of cross-regional and/or cross-class actions. Hence the roundup in 1999 of Democracy Party activists (who had established branches across the country with participation from workers as well as intellectuals), and hence the antipathy toward Falun Gong. That the Internet was evidently serving as a mobilizational weapon for Falun Gong practitioners, as it had for Democracy Party members as well, was also highly disturbing to the leadership. This new means of communication was capable of easily transcending spatial and occupational barriers and was also stubbornly resistant to state surveillance efforts.

Of further concern was the fact that so many Falun Gong adepts were members of the Communist Party, including high-level officials in the government and army. Although participation (and even leadership) by party cadres and PLA soldiers in sectarian unrest is by no means unprecedented, in the past those involved were generally low-level officials without national influence. In this case, however, the former director of the 301st Army Hospital in Beijing - a doctor with considerable standing among the political elite - had been advising high-level cadres to turn to Falun Gong. At a time when CCP leaders find themselves ideologically adrift and presiding over an increasingly moribund party apparatus, the emergence of a large social movement whose diverse membership exhibits remarkable commitment and enthusiasm, has the capacity to mobilize on a nationwide scale, and maintains secure international communications, is anything but a welcome development.

Here, too, historical memories are disturbing. Much of the explanation for the Communists' rapid rise to victory half a century ago lay in the defection of so many elements of the ancien regime. When Guomindang members at all levels began to go over to the Communist side, the civil war tilted decisively in favor of the revolutionaries. ${ }^{10}$ Thus Jiang Zemin was understandably wary of the fact that many CCP members had joined the Falun Gong.

Whether one interprets the regime's reaction against Falun Gong as rational suspicion or as irrational paranoia, the contradictions of the campaign have laid bare many of the ironies of Communist rule. When the campaign was first launched, the authorities declared Falun Gong to be a "heterodox religion" (xiejiao $)$ - the traditional term employed by the imperial Chinese state to designate those groups, such as the millenarian White Lotus Society, whose practices were deemed antithetical to its own Confucian dictates. In such a discourse, "heterodox religion" is contrasted to "orthodox religion" — whether of the Confucian or Communist persuasion. The initial wave of the campaign counterposed the "heterodox" views of Falun Gong leader Li Hongzhi to the correct tenets of Marxism-Leninism. Whereas Marxism-Leninism championed materialism, Falun Gong espoused idealism. Rather than be misled by the false teachings of the charismatic Li Hongzhi, citizens were enjoined to rally around the central party leadership and its proper doctrines. Framing the problem in this fashion had the unintended effect, however, of putting Falun Gong on a roughly equal footing with the Communist Party. On the one side stood Li Hongzhi and his heterodox teachings, on the other side the central leaders and their orthodox teachings. In the interests of stability and unity, ordinary Chinese were asked to reject Falun Gong in favor of the CCP. 
The unwitting implication was that two competing sects were locked in mortal combat, each vying for the allegiance of the masses. When the state accused Falun Gong of having caused numerous deaths through suicide, starvation, and mental illness, one could hardly help but compare its record favorably against the devastation wrought by Land Reform, the Great Leap Forward, and the Cultural Revolution — not to mention the June Fourth massacre.

Perhaps it dawned on someone in the Ministry of Propaganda that this was not a particularly flattering way in which to represent the Communist Party. In any event, after a few days of this approach, the campaign took a new turn. Instead of contrasting Falun Gong "heterodoxy" to Communist "orthodoxy," the principal opposition was now presented as one of "superstition" versus "science." Prominent astronomers and physicists from the major universities and research academies were trotted out to denounce Li Hongzhi's apocalyptic prophecies about the end of an age (moshilun). Whereas Li had allegedly predicted the advent of a comet that would generate a global explosion that only he could deflect, scientists responded that the chances of such an occurrence that year were a remote one in fifty billion. Nonetheless, they proceeded soberly to calculate the precise force that Li Hongzhi would have to be able to muster in order to repel such a comet were it in fact on its way, and pronounced his alleged boast "impossible!" Meteorologists for the evening television news also took care to reassure viewers that the partial lunar eclipse on July 28 was no cause for alarm — despite popular beliefs that unusual astrological occurrences are a sign of the loss of the Mandate of Heaven.

Physicians and psychiatrists testified to the deleterious physical and mental health effects of Falun Gong. Television cameras took viewers inside mental institutions to observe cases of "qigong deviation" (qigong piancha), a Chinese category of mental illness allegedly brought on by the practice of Falun Gong techniques. Victims of Falun Gong, not previously noted for filling mental hospitals, were now said to account for more than 40 percent of the patients in Chinese psychiatric wards. Psychologists explained how continuous exposure to the books, tapes, videos, Internet home page, and other paraphernalia of Falun Gong could induce a "true believer" mentality in which followers would be willing to follow blindly any command issued by the supreme leader.

To be sure, government officials were not without some justification in highlighting the bizarre belief system that underpinned the practice of Falun Gong. Followers of the faith were said to derive therapeutic benefits from the regular rotation of a spiritual wheel implanted in their stomachs by the charismatic authority of Li Hongzhi. Those who mastered the regimens of the religion were promised supernatural powers that ranged from levitation to x-ray vision. And, unlike many other qigong groups, Falun Gong believers seemed to devote at least as much energy to honoring their leader — who was invested with divine attributes - as to honing their exercise skills.

Attuned to the international backlash that the repression campaign was bound to generate, government television stations invited experts in law and philosophy to explain that suppression of an unregistered, and thus illegal and illegitimate, organization was not a violation of human rights. Social scientists 
testified that Falun Gong's capacity to amass large numbers of otherwise unconnected people simultaneously was a clear threat to the general social order something that could not be tolerated in any modern polity. Officially sanctioned religious specialists decried the "feudal superstition" of Falun Gong, in contrast to the "normal religion" that they themselves espoused.

For weeks after the campaign began, each night pictures were broadcast of huge piles of Falun Gong materials that had been either voluntarily turned over by practitioners or confiscated in police raids on bookstores and publishing houses. (Interestingly, the People's Liberation Army Press was responsible for a number of Falun Gong publications.) Some were disposed of in gigantic bonfires, others were recycled. Relatives of Falun Gong victims testified about the terrible tragedies that had befallen their loved ones. Former adherents also began to come forward to explain how they had been hoodwinked by Li Hongzhi and to express regret at their gullibility. Physical education teachers pointed to healthy alternatives to Falun Gong in the form of badminton, ballroom dancing, bowling, and the like. Happy pictures of those who had kicked the Falun Gong habit and were now pursuing more benign varieties of exercise began to flood the evening news.

The basic patterns of the government's offensive were familiar from decades of previous such mobilized suppression efforts, from the anti-rightist campaign of the 1950s to the anti-spiritual pollution campaigns of the 1980s. However, judging from discussions with people in China at the time, this particular campaign was not a resounding success. While most of those with whom I talked accepted that Falun Gong's organizational capacities were a potential danger and assumed that Li Hongzhi was a hustler with a nefarious agenda, be it political or simply pecuniary, they found the government's treatment of the case something of a public embarrassment. The draconian nature of the campaign was suggestive of a deeply frightened and insecure central leadership. People wondered out loud: Had crimes so serious as to warrant the arrest of thousands really occurred?

The state produced no convincing evidence to demonstrate any actual disruption of public order from Falun Gong - aside from the fact that so many of its own cadres had enlisted in the movement. ${ }^{11}$ Although the authorities tried to argue that Falun Gong members were interfering with flood control work by demonstrating outside public agencies, the television footage revealed that entrances and exits to public buildings had been kept conspicuously open by Falun Gong protesters. The gatherings were non-violent and remarkably disciplined. While the government insisted that these demonstrations were the most serious political threat since the 1989 student uprising, it was hard to see why.

The weakness of the state's case was plain, its accusations rife with obvious inconsistencies, ironies, and exaggerations. The government claimed to be justified in cracking down on the group because it was not officially registered, but the Falun Gong demonstrations had been prompted precisely by a desire for the official recognition and registration that the state refused to grant. The authorities castigated Falun Gong for being feudal and un-scientific, while at the same time denouncing its use of cutting-edge Internet technology to propagate its message both nationally and internationally. 


\section{Historical Analogies}

One of the greatest ironies of the campaign lay in the state's reluctance to acknowledge the historical considerations that so clearly lay behind its heavyhanded reaction to Falun Gong. As everyone with whom I spoke was quick to point out, the real fear was that the movement would turn into the sort of sectarian-inspired rebellion for which Chinese history is famous. Indeed, by labeling the group a "heterodox sect" (xiejiao) and cracking down relentlessly on its practitioners, the authorities invited just such historical allusions. From the Yellow Turbans to the White Lotus to the Boxers, the folk religion and breathing regimens of "heterodox sects" proved to be a volatile mix in times of dynastic crisis. Although the official media did not draw attention to this historical analogy, it was certainly not lost on the public at large. The fact that a popular central television serial chronicled the story of the first Ming emperor, Zhu Yuanzhang - a mendicant monk whose fourteenth century rise to power came in the midst of a White Lotus-inspired rebellion — served only to highlight the linkage between past and present. Fear of the loss of the Mandate of Heaven was generally seen as the driving force behind the campaign, but this "feudal superstitious" belief could of course not be officially admitted.

As the historical record teaches us, the vast majority of Chinese sectarian groups were inclined toward political quiescence. The trigger for protest, more often than not, lay with the state. Government repression was a common precipitant of overt rebellion. ${ }^{12}$ Thus if the current effort to eliminate Falun Gong
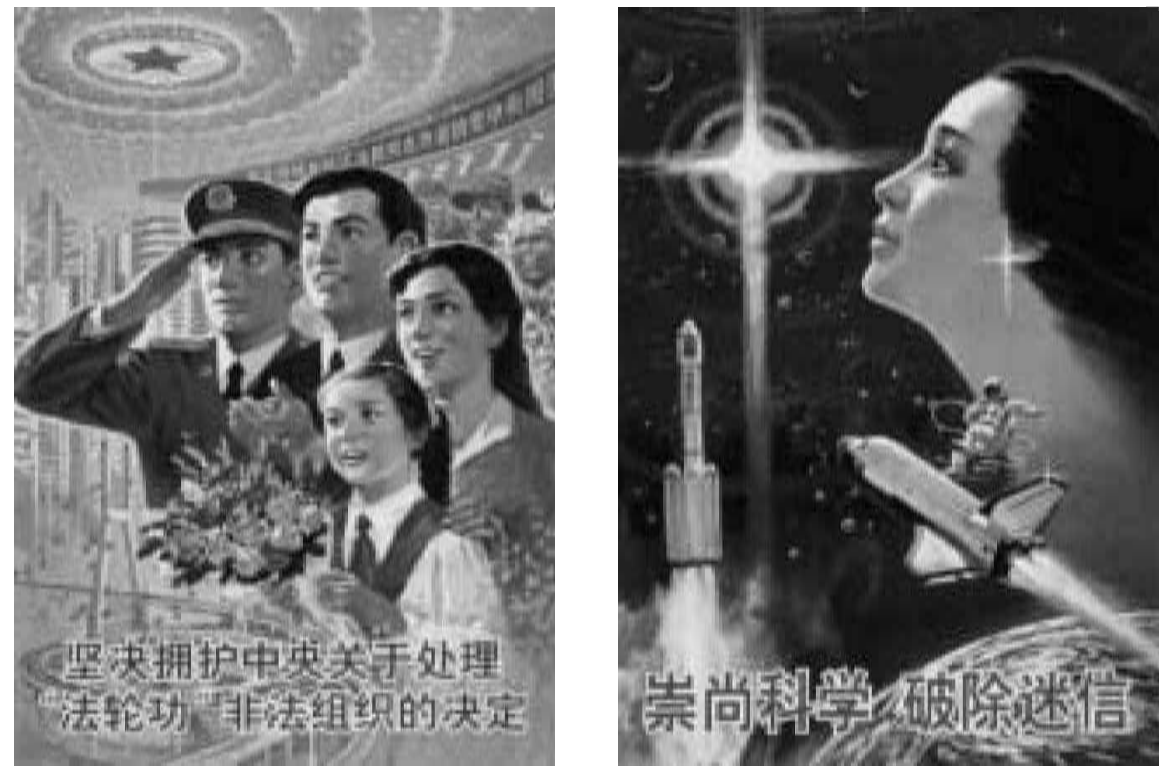

Anti-Falun Gong posters. Designer: Cheng Guoying. From the collection of Stefan Landesberger. (Left) E13/892. Jianjue yonghu Zhongyang guanyu chuli "Falun Gong" feifa zuzhide jueding [Firmly support the decision of the Central Committee to deal with the illegal organization of "Falun Gong"], Sichuan meishu chubanshe, August 1999, print no. 85410.

3590. (Right) E13/891. Chongshang kexue, pochu mixin [Uphold science, eradicate superstition],Sichuan meishu chubanshe, August 1999, print no. 85410.3589. 
does not succeed, the authorities are likely to have turned a once tranquil friend into an implacable and formidable foe. Like the anti-sectarian efforts of the Qianlong emperor in the eighteenth century, or for that matter of the Guomindang earlier in the twentieth century, their heavy-handed initiatives against "heterodoxy" and "feudal superstition" may well prove counterproductive in the long run. ${ }^{13}$

Whether or not the government prevails in its effort to eliminate Falun Gong as an organization, the suppression campaign exposed profound vulnerabilities in the state's grip on society. Equally important, the sorts of demonstrations sweeping China at the turn of the millennium — whether launched by qigong practitioners or by anti-American students - served notice that popular protest in China is not a carbon copy of the social movements familiar in Western societies. As analysts, we would do well to approach such expressions of public sentiment on their terms, rather than assume (as many outside observers did during the Tiananmen demonstrations more than a decade ago) that the wellsprings of political change lay only with those marching behind a replica of the Statue of Liberty.

Throughout Chinese history, mass protests have played a special role in bestowing political legitimacy - whether according to Confucian or Communist principles. This contributes to a distinctive dynamic of state-society relations. On the one hand, Chinese political culture (whether framed in terms of the Mencian Mandate of Heaven or in terms of Mao's Mass Line) encourages and empowers protesters to rise up from the ranks of society to challenge state leaders. On the other hand, precisely because of the importance of popular protest to political legitimacy, state authorities - be they emperors or general secretaries of the Communist Party - move aggressively to condone or to condemn particular outbreaks of protest activity. Popular demonstrations that go beyond the articulation of local economic grievances are either welcomed as supportive of the reigning orthodoxy or else they are banned as expressions of heterodox superstition. As a result, Chinese protesters themselves are unusually attentive to signals from the state. The request by Falun Gong adherents for official recognition and registration is only the latest in a centuries-old tradition of appeals by social movements for government approval.

The close relationship between state authorization and social movements in China raises some questions concerning the applicability of general theories of contentious politics, developed for the most part on the basis of European and American cases. Although these theories have certainly not ignored the role of the state, they have generally been content to suggest a negative correlation between state strength and politically threatening social movements. Revolutions, according to this line of analysis, are facilitated by weak states incapable of repressing challenges to their own survival. ${ }^{14}$ There is, of course, an obvious - possibly even tautological — logic to this insight that applies, at least in hindsight, to any revolutionary outcome. But the Chinese experience argues for acknowledging a larger, more pro-active role for the state.

It is not just that state weakness may encourage protest; rather, popular protests are often inspired by the very strength of state exemplars. Take Falun 
Gong, whose organizational structure closely resembles that of the Chinese Communist Party. In both cases, individuals belong to local branches whose leaders are strictly subservient to the directives of the next level in a tightly organized, territorially based hierarchy. While ordinary members of one branch may have little direct contact with members of other branches, their leaders are plugged into an extremely effective system of communication and command. Prior to the government crackdown, Falun Gong boasted more than 28,000 local branches (known as liangongdian or practice points) whose leaders reported to more than 1,900 supervisory stations (fudaozhan) that in turn reported to thirty-nine general stations (zongzhan) at the level of province, autonomous region, and municipality. At the center stood the Wheel of Law Research Society (falun dafa yanjiubui).

The structural isomorphism between Falun Gong and the Communist Party was due not only to Falun Gong's desire to elude state surveillance through a dispersed cellular pattern (perfected by the CCP during its own revolutionary years for a similar purpose). The congruence was due also to the fact that the Communist Party represents an extremely powerful, indeed virtually irresistible, organizational template for any group trying to operate in contemporary China.

By the same token, territory designated as politically sacred by the Chinese state exerts a tremendous pull on potential protesters. Thus, despite the enormous dangers inherent in public assemblies at Tiananmen Square, members of the outlawed Falun Gong movement are drawn back again and again to that site precisely because it is the state-sanctioned political center of the country. A Reuters report during the lunar New Year's celebrations in February 2000 makes clear this magnetic, mimetic connection between the Chinese state and its would-be challengers:

Defiant members of the Falun Gong spiritual movement kept up protests in Tiananmen Square on Saturday after the banned group marked the Year of the Dragon with one of its biggest demonstrations on the vast plaza. Plainclothes police swarmed the square, detaining at least half a dozen people, the morning after scores of Falun Gong protesters tried to unfurl Buddhist banners near China's most prominent flagpole bearing the national standard.

As lunar New Year's revelers looked on, police swooped across the square and detained more than 100 people, kicking and punching some, witnesses said....Despite the beatings, Falun Gong members kept up chants of "Falun Dafa" - "Great Law of the Wheel" - even inside the detention centre. The demonstration is the latest evidence that a nationwide crackdown has failed to crush members' allegiance to the group which China's Communist leaders banned in July last year and labeled an "evil cult" in October. Authorities have done their utmost to keep Falun Gong members from the capital, checking identity cards at railway and bus stations, and setting up roadblocks on routes into the city. They have handed out harsh jail sentences to Falun Gong leaders, and detained thousands of members. Yet Falun Gong has been attempting ever bolder acts of protest. 
Last month [February 2000], members tried to hang a giant portrait of their U.S.-based guru, Li Hongzhi, over the painting of Mao Zedong which overlooks the square, the Information Centre of Human Rights and Democratic Movement in China has reported. ${ }^{15}$ (my emphasis)

As this news report indicates, intense state repression may work to radicalize — rather than eliminate - popular protest. This phenomenon has already begun to receive some atten tion in the literature on social movements, ${ }^{16}$ but the ways in which state practices themselves encourage imitation by protesters remains under-appreciated. The provocative substitution of Buddhist banners for the national flag and of Master Li's portrait for that of Chairman Mao suggest the tremendous temptations that the official trappings of state hold even for those who rise up to challenge the powers-that-be.

The tendency for protesters to take cues from official symbols of authority can be found in any polity, but it is particularly pronounced in authoritarian systems where the state exercises a virtual monopoly over political discourse. In such contexts, the clever appropriation and inversion of officially sanctioned rituals and ceremonies for subversive purposes is a prominent feature of protest behavior. In China, where popular protest is culturally sanctioned and where the custom of "waving the red flag to oppose the red flag" has an ancient pedigree that long predates the Communist era, this practice has been honed into a high — and often highly ironic — art form.

Just as various democratic political cultures have given definition to distinctive French, English, and American repertoires of collective action, so authoritarian societies also manifest identifiable styles of protest. In China, the ironic invocation (and, through puns, the inversion) of official rhetoric, the creative use of historical allegory, and the counter-hegemonic commemoration of statesponsored holidays are exceptionally well-developed means of challenging authority (just as Russian political culture is famed for its sardonic jokes). China offers rich material from which to develop a better understanding of such phenomena, while serving at the same time to exemplify a more general type of political system in which the boundaries between state and society are less starkly drawn than in liberal democracies. Although China (with the exception of contemporary Taiwan) has never enjoyed democratic rule, it has experienced a variety of authoritarian regimes: imperial, Republican, and Communist.

Those who hold the reins of power in Beijing today are of course acutely aware of this historical record. It is precisely in light of the familiar Chinese past — including the history of the Chinese Communist Party itself - that the regime's seemingly inconsistent and illogical responses to contemporary protests become explicable. While popular protest in China bears a definite resemblance to unrest in other authoritarian polities, the differences are also stark and significant. Sidney Tarrow writes of authoritarian states in general:

That authoritarian states discourage popular politics is implicit in their very definition. In particular, they suppress the sustained interaction of collective actors and authorities that is the hallmark of social movements.... Repressive states depress collective action of a conventional and confrontational sort, but leave themselves open to unobtrusive mobilization. ${ }^{17}$ 
Like other authoritarian societies, the PRC has certainly witnessed the development of what James Scott terms a "hidden transcript" of critical dissent. ${ }^{18}$ But Communist China parts company with these other countries in having periodically encouraged — indeed compelled — its citizens to express their private criticisms publicly in the form of big-character posters, struggle sessions, denunciation meetings, demonstrations, and the like. The Cultural Revolution was the most dramatic, albeit certainly not the only, instance of this effort. The Communist state's sponsorship of mass campaigns is related to a fundamental tenet of Chinese political culture that links effective popular protest and political legitimacy. Although Mao's mass line departs significantly from Mencius's Mandate of Heaven, they share the belief that "to rebel is justified."

\section{Repercussions}

State sponsorship of public criticism in China has had a number of important repercussions. For one thing, ordinary Chinese are simply more familiar with modes of collective protest than we would expect of a population living under such tight political supervision. Ritualized as some aspects of mass criticism became during the Cultural Revolution, these routines nonetheless constituted part of a rich repertoire of protest techniques available to city dwellers and country folk alike. Public experience with protest may well explain why it was China that got the revolutionary ball rolling across the Communist world in 1989. It surely helps explain how the Tiananmen protesters proved so skillful at capturing worldwide attention with their dramatic actions: festive marches complete with colorful banners and stirring music; stinging attacks on political au thorities in wall posters, speeches, and televised debates; even somber hunger strikes - all found precedents in earlier, elite-inspired campaigns.

Yet ultimately the voicing of the hidden transcript proved far more unsettling elsewhere in the Communist world than turned out to be the case for China. Precisely because protest was both routine and officially circumscribed, once the top leadership initiated a clear course of repression most of the populace was quick to fall into step - with concerns for personal safety and perhaps stability rapidly overshadowing the euphoria of public criticism. After all, this too was a familiar drill — harking back to the anti-rightist campaign of 1957, the military suppression of Cultural Revolution mass activism in 1969, the clearing of Tiananmen Square in April 1976, and the clampdown on Democracy Wall in 1979. In China, unlike Eastern Europe or the Soviet Union, both leaders and ordinary citizens knew how to put the genie of mass protest back into the bottle of state socialism.

What this augurs for the future is of course impossible to predict with confidence. Certainly the post-Mao reforms are generating new pretexts for protest, as concerns about excessive taxes and factory closures have joined long-standing resentment toward official privilege and bureaucratic corruption. Equally significant, the opportunities for forming cross-class and cross-regional coalitions are expanding apace with the unraveling of many of the state-imposed 
controls of the Maoist era. Much will depend upon the way in which the government authorities choose to respond to the growing unrest in both cities and countryside. Regardless of how the evolving tensions play out, however, upcoming scenarios are certain to bear the imprint of past practices - including those of Chinese Communism itself.

Maoist initiatives continue to influence modes of thought and behavior in the contemporary post-Mao period, but in many ways China today resembles the China of the Republican - or even the late imperial — era more than it does the China of Mao's Cultural Revolution. As markets reemerge and state-erected social barriers crumble, class relations are reconfigured in a manner that may well rekindle the fires of rebellion and revolution that burned so brightly in an earlier age. The powerful cross-cutting social coalitions of the late nineteenth and early twentieth centuries were in part a product of relatively weak state capacity, but more importantly they also reflected the appearance of new social classes (e.g., an industrial proletariat) and new social identities (e.g., youths and women).

These developments had momentous implications for the nature of protest, helping give rise to such massive and politically significant events as the May Fourth Movement of 1919, the May Thirtieth Movement of 1925, and the Civil War unrest of the late 1940s. Under the Republic, the notion of urban citizenship (shiminquan) took on special meaning, implying a new and powerful claim for urban residents of all social classes to participate in local politics. Fueled by an alliance of intellectuals, workers, and merchants, successive waves of popular contention during the first half of this century constituted a dramatic turning point in Chinese history.

Although these expressions of newfound community and discontent paved the way for the victory of Communism, the Maoist state reversed such trends, severely constraining the possibility of cross-class initiatives. In a manner to which his imperial predecessors aspired, but never fully attained, Mao proved amazingly adept at limiting potentially threatening societal interaction.

During the Maoist period, a rigid household registration system (bukou zhidu) was imposed that severely restricted migration and effectively severed relations between villagers and urbanites. Moreover, within cities separate places of recreation were established for workers and intellectuals, while the bourgeoisie was virtually eliminated. Gone were the teahouses and cafes that had served as meeting places for members of different classes during the Republican era. Workers now spent their leisure time at workers' cultural palaces, while intellectuals congregated at writers' and artists' associations. In the post-Mao period, the breakdown of these social restrictions may once again encourage cross-class alliances with a potential for politically powerful collective action.

Much has changed over the past half century, of course, from cultural values to technological advances. And yet, to the extent to which popular protest and political legitimacy remain inextricably linked in the public mind, we can anticipate that future generations of Chinese may also rise up to challenge the Mandate of Heaven. 


\section{Notes}

This article is drawn from the introductory chapter of Challenging the Mandate of Heaven? Popular Protest and State Power in China (Armonk, N.Y.: M.E. Sharpe, forthcoming). The volume offers a revised selection of the author's previously published essays on Chinese popular protest, from late imperial days to the present.

1. Liu Xiaobo, "That Holy Word, 'Revolution,'” in Popular Protest and Political Culture in Modern China, ed. Jeffrey N. Wasserstrom and Elizabeth J. Perry (Boulder, Colo: Westview Press, 1994), 315, 318.

2. Elizabeth J. Perry, "Chinese Anniversaries in International Perspective," Harvard Asia Quarterly 3, no. 3 (summer 1999).

3. See Jeffrey Wasserstrom, “The Year of Living Anxiously: China's 1999" (Dissent, spring 2000) for an insightful discussion of historically grounded differences in government reactions to two of the three types of movements discussed here — which Wasserstrom dubs the "Solidarity Scenario" and the "Religious Revolt Scenario."

4. Foreign Broadcast Information Service (FBIS), 8 August 1994, 18.

5. Ching Kwan Lee, "Pathways of Labor Insurgency," in Chinese Society: Change, Conflict, and Resistance, ed. Elizabeth J. Perry and Mark Selden (London: Routledge, 2000).

6. FBIS, 11 June 1993, 13.

7. Jeffrey Wasserstrom makes this point in "The Year of Living Anxiously."

8. Elizabeth J. Perry, "Rural Collective Violence: The Fruits of Recent Reforms," in The Political Economy of Reform in Post-Mao China, ed. Elizabeth J. Perry and Christine Wong (Cambridge, Mass.: Harvard University Press: 1985); and Elizabeth J. Perry, "Crime, Corruption and Contention in Contemporary China," in The Paradox of China's Post-Mao Reforms, ed. Merle Goldman and Roderick MacFarquhar (Cambridge, Mass.: Harvard University Press: 1999).

9. Dangdai (The present age), no. 39 (25 August 1990), 14-15; FBIS, 26 December 1990, 29.

10. Suzanne Pepper, Civil War in China: The Political Struggle, 1945-1949 (Berkeley and Los Angeles: University of California Press, 1978).

11. In Shanghai, for example, I was told by the vice-director of the Propaganda Bureau that more than 10 percent of the 5,000-plus Falun Gong practitioners in the city were party members.

12. Daniel L. Overmyer, Folk Buddhist Religion: Dissenting Sects in Late Traditional China (Cambridge, Mass.: Harvard University Press, 1976).

13. Prasenjit Duara, "Knowledge and Power in the Discourse of Modernity: The Campaigns against Popular Religion in Early Twentieth-Century China, Journal of Asian Studies 50, no. 1 (1991): 67-83.

14. Charles Tilly, From Mobilization to Revolution (Reading, Mass.: Addison-Wesley, 1978); and Theda Skocpol, States and Social Revolutions (Cambridge: Cambridge University Press, 1979).

15. Reuters World Report, 5 February 2000.

16. Donatella Della Porta, Social Movements, Political Violence, and the State: A Comparative Analysis of Italy and Germany (Cambridge: Cambridge University Press, 1995).

17. Sidney Tarrow, Power in Movement: Social Movements, Collective Action and Politics (New York: Cambridge University Press, 1994), 92-93.

18. James C. Scott, Domination and the Arts of Resistance: Hidden Transcripts (New Haven, Conn.: Yale University Press, 1990). 